\title{
Trend of mortality from ischemic heart disease and influenza vaccination in older adults in São Paulo
}

\author{
Tendência da mortalidade por doenças isquêmicas do coração \\ e a vacinação contra influenza em idosos em São Paulo
}

Aldiane Gomes de Macedo Bacurau (https://orcid.org/0000-0002-6671-2284) ${ }^{1}$
Rosemeire de Olanda Ferraz (https://orcid.org/0000-0001-5796-946X) ${ }^{1}$
Maria Rita Donalisio (https://orcid.org/0000-0003-4457-9897) ${ }^{1}$
Priscila Maria Stolses Bergamo Francisco (https://orcid.org/0000-0001-7361-9961) ${ }^{1}$

${ }^{1}$ Departamento de Saúde Coletiva, Faculdade de Ciências Médicas, Universidade Estadual de Campinas. R. Tessália Vieira de Camargo 126, Cidade Universitária. 13083-887 Campinas SP Brasil. aldianemacedo@ hotmail.com

\begin{abstract}
The aim of the present study was to analyze the mortality trend due to ischemic heart disease (IHD) among older adults, identify changes in the trend and determine the correlation with influenza vaccine coverage (2000 to 2012) in the state of São Paulo between 1980 and 2012. An ecological time series study was conducted involving secondary data from Brazilian information systems. Linear and polynomial regression models as well as joinpoint regression were used to estimate the trends. Pearson's correlation coefficient was used to evaluate the correlation between age -standardized mortality coefficients and vaccine coverage. A decreasing tendency in mortality due to IHD occurred in both sexes, higher mortality rates were found for males and greater reductions were found in the period after the vaccination campaigns. However, no statistically significant changes occurred in the year coinciding with or near the onset of the campaigns. In the overall sample, no evidence of a linear correlation was found between the mortality coefficients and vaccination coverage. Other factors directly associated with morbidity and mortality due to ischemic heart disease may have influenced the trend.

Key words Mortality, Health of the elderly, Cardiovascular diseases, Myocardial ischemia, Influenza vaccines
\end{abstract}

Resumo O objetivo deste artigo é analisar a tendência dos coeficientes de mortalidade por doenças isquêmicas do coração (DIC) nos idosos no estado de São Paulo, entre 1980 e 2012, identificar mudanças na tendência e verificar a relação entre as coberturas da vacinação contra influenza e os referidos coeficientes de mortalidade. Trata-se de um estudo ecológico de série temporal, realizado com dados secundários do Sistema de Informação sobre Mortalidade (SIM), do Instituto Brasileiro de Geografia e Estatística (IBGE) e do Sistema de Informações do Programa Nacional de Imunização. Para análise dos dados, utilizaram-se técnicas de correlação, modelos de regressão linear, polinomial e joinpoint regression. Observou-se tendência de queda dos coeficientes de mortalidade por DIC em ambos os sexos, sobremortalidade masculina e redução mais expressiva dos coeficientes no periodo após a intervenção vacinal. As mudanças estatisticamente significativas encontradas nas tendências não ocorreram em ano coincidente ou próximo do início das campanhas. Para o total de idosos, não foi constatada correlação linear entre os coeficientes de mortalidade e as coberturas vacinais. Outros fatores associados à morbimortalidade dos idosos por DIC podem ter influenciado na tendência.

Palavras-chave Mortalidade, Saúde do idoso, Doenças cardiovasculares, Doença isquêmica do coração, Vacinas contra influenza 


\section{Introduction}

Cardiovascular disease exerts considerable impact on morbidity and mortality rates throughout the world. The main risk factors are arterial hypertension, diabetes mellitus, dyslipidemia, smoking, physical inactivity, abusive alcohol intake, overweight/obesity and inadequate eating habits. Other determinants include poverty, stress, age and hereditary factors ${ }^{1}$.

In Brazil, cardiovascular disease has been the major cause of death for decades, with high prevalence rates of complications associated with ischemic heart disease (IHD) and cerebrovascular disease, which have a huge impact on the morbidity of the population ${ }^{2,3}$. Among older adults, these diseases account for high hospitalization and outpatient follow-up costs and continue to be the major cause of death ${ }^{2,4}$.

Studies have shown that infection by influenza is associated with an increase in mortality among older adults and individuals with chronic diseases $^{5-9}$. According to the US Centers for Disease Control and Prevention, previous infection by influenza is a risk factor for death caused by acute myocardial infarction, vascular disease and diabetes. However, these deaths are not counted together with those due to pneumonia and influenza and the impact of the disease on the mortality rate may be underestimated ${ }^{8}$.

The literature reports an increase in deaths and cardiovascular events during flu epidemics in the past century ${ }^{10,11}$. In Brazil, chronic cardiovascular disease was the second most prevalent adverse health condition among patients who died during the pandemic of the H1N1 virus in 2009, surpassed only by chronic respiratory disease ${ }^{12}$.

Strategies for the reduction and control of morbidity and mortality due to non-communicable chronic diseases among older adults include primary prevention services, such as vaccination $s^{13}$. An annual vaccination against the flu is recommended for older adults and individuals with chronic diseases, such as cardiovascular disease, as a strategy to reduce the morbidity and mortality rates associated with infection by the influenza virus ${ }^{13-15}$.

According to the Brazilian Cardiology Society, vaccination against influenza and pneumococcus reduces the number of hospitalizations due to heart failure among older adults ${ }^{16}$. Mansur et al. ${ }^{17}$ analyzed mortality rates due to cardiovascular diseases among older adults in the metropolitan region of the city of São Paulo before and after flu vaccines and found a significant reduc- tion in deaths due to IHD after the introduction of immunization campaigns for the elderly. The benefits of the flu vaccine for individuals with cardiovascular disease have been investigated and despite not presenting unanimous results, most studies indicate a protective effect, especially with regard to heart-related outcomes ${ }^{7,17}$. In Brazil, the relationship between the flu vaccine and mortality due to cardiovascular disease remains under-investigated and divergent findings are reported $^{17,18}$.

The aims of the present study were to analyze the mortality trend due to ischemic heart disease (IHD) in the population of older adults ( $\geq 60$ years of age) in the state of São Paulo in the periods before (1980 to 1997) and after (1998 to 2012) the beginning of flu vaccination campaigns, identify change points in trends throughout the entire period and determine the correlation between flu vaccine coverage and mortality coefficients between 2000 and 2012.

\section{Methods}

An ecological time series study was conducted with data from the Mortality Information System (SIM) of the Brazilian Health Ministry by the Department of Informatics of the Public Healthcare System (DATASUS). SIM/DATASUS stores data on deaths through the collection of information from death certificates. Population estimates were based on census data from the Brazilian Institute of Geography and Statistics (IBGE), which were also taken from the DATASUS website.

The variables studied were year of death, sex (male and female), age group (60 to 69, 70 to 79 and $\geq 80$ years), specific mortality rate for selected cause (IHD) and vaccination coverage. Codes 410 to 414 in Chapter VII of the $9^{\text {th }}$ Revision of the International Classification of Diseases (ICD9) were used for deaths due to IHD between 1980 and 1995 and codes I20 to I25 in Chapter IX of the $10^{\text {th }}$ revision (ICD-10) were used for deaths between 1996 and 2012.

Data on flu vaccine coverage in the state of São Paulo between 2000 and 2005 were acquired from the Technical Bulletin of the Immunization Division of the Epidemiological Surveillance Center of the State Secretary of Health ${ }^{19}$. For the period between 2006 and 2012, data on vaccine coverage were acquired from the site of the Information System of the National Immunization Program (SI-PNI). 
The mortality trend due to IHD in the elderly population between 1980 and 2012 was estimated from standardized mortality coefficients using the direct method ${ }^{20}$ (the population of the state of São Paulo from the 2010 Census was used as the standard population) as well as specific coefficients per sex and age group (60 to 69, 70 to 79 and $\geq 80$ years) for every 10,000 inhabitants. For each year, the standardized male/female coefficient ratio was calculated to track changes in this ratio over time using a simple linear regression model with a $5 \%$ significance level.

Prior to adjusting the models, dispersion diagrams were plotted using data related to mortality coefficients and the years studied to enable the visualization of the trend. From the observed relationship, simple or polynomial regression models were estimated, which are easy to create and interpret and have considerable statistical power. The modeling process was performed considering the mortality coefficients as the dependent variable ( $\mathrm{Y}$ axis) and the years studied as the independent variable ( $\mathrm{X}$ axis). A centered-year variable (1996) was used to mitigate the serial correlation between the terms of the regression equation ${ }^{21}$.

The most parsimonious model was selected and the coefficient of determination $\left(\mathrm{R}^{2}\right)$ was used as the goodness-of-fit measure ${ }^{22}$. A p-value $<0.05$ was considered indicative of a significant trend. For models that were similar from the statistical standpoint, the simpler one was selected. Adherence to normal distribution was determined using the Shapiro-Wilk test, the supposition of equal variance was investigated using White's test and the absence of serial correlation of the variables was determined using the Breusch-Godfrey test.

A segmented regression analysis (joinpoint regression) was also performed to identify possible significant changes in the trend throughout the period. This model assumes a linear trend between inflexion points and works with the same presuppositions as the simple linear regression model, except those of independence (non-autocorrelation) and constant variance (homoscedasticity). Besides identifying the number and location of changes in the mortality trend, joinpoint regression enables estimating the Annual Percent Change (APC) in each of the periods demarcated by the inflexion points. This model was also used to obtain a summary measure of the trend between 1980 and 2012, represented by the Average Annual Percent Change (AAPC) ${ }^{23}$. The selection of the number of significant junction points was performed automatically by the Joinpoint Regression Program. The existence or absence of homoscedasticity and non-autocorrelation was determined and incorporated into the configurations of the software program for the adjustment of the models.

A 5\% significance level and $95 \%$ confidence intervals were used for the choice of the model with the best fit. Pearson's correlation coefficients (r) were calculated for the determination of the strength of correlations between coefficients of mortality due to IHD and vaccine coverage between 2000 and 2012. The following software programs were used for the organization of the data and statistical analyses: Excel $2013^{\circledR}$, SPSS version 21, STATA version 12 and Joinpoint Regression Program version 4.3.1.0 (Statistical Research and Applications Branch, National Cancer Institute, Rockville, USA), which is provided free of charge by the US National Cancer Institute.

\section{Results}

Between 1980 and 2012, 561,772 deaths due to IHD among the elderly population were registered in the state of São Paulo. The standardized mortality coefficients diminished among older adults of both sexes throughout this period (Figure 1; Table 1). For the male sex, the mean mortality coefficient due to IHD in the period was 78.18 deaths per 10,000 men, with a constant linear regression of -1.77 per year. For the female sex, the mean coefficient was 59.27 deaths per 10,000 women, with a constant linear reduction of -1.71 per year. The mortality rate among men was higher in all years and the standardized male/female mortality coefficient ratio increased throughout the period $(\mathrm{p}<0.001)$, with a mean coefficient of 1.34 male deaths for each female death, which demonstrates the importance of IHD in the male population, especially over time (Table 1).

The analysis of the mortality trend due to IHD according to age group revealed a greater magnitude in the mean annual increase in older age groups for both males and females. Table 2 displays the regression coefficients and statistical significance of the mortality trend due to IHD according to sex and age group. Among males aged 60 to 69 years, the mean coefficient in the period $\left(\beta_{0}\right)$ reached nearly twofold that found in the female population in the same age group. The male and female population aged 80 or older stands out due to the magnitude of the mean 


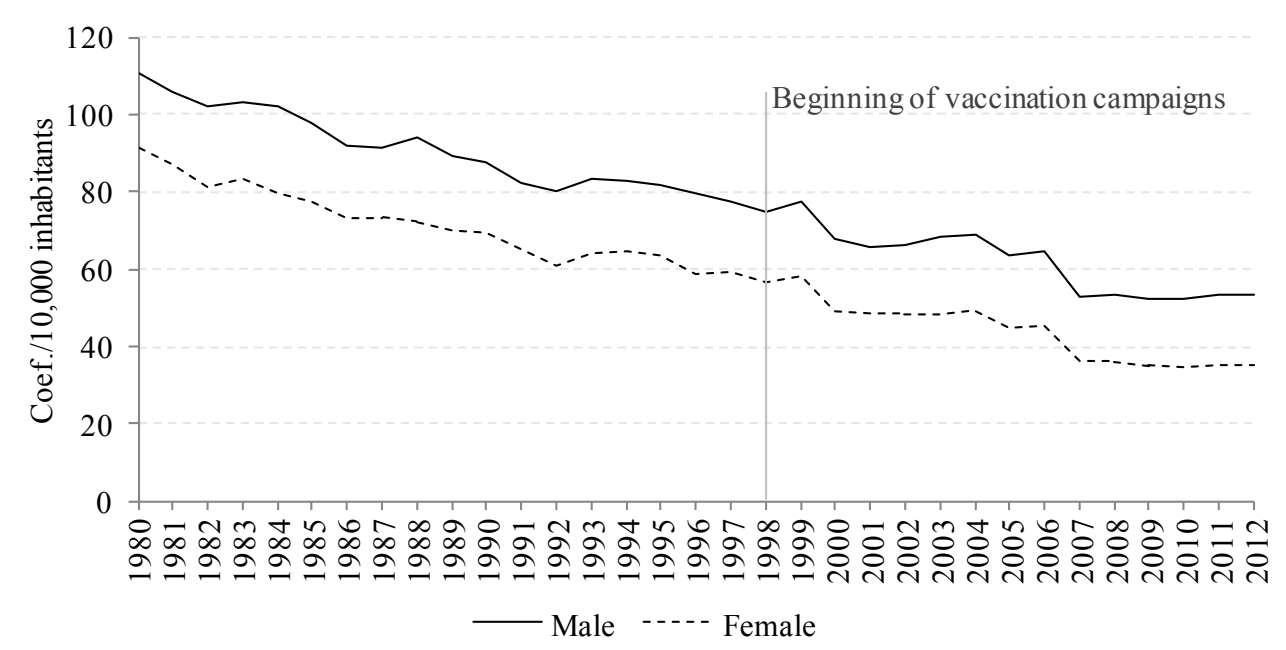

Figure 1. Standardized coefficients of mortality due to ischemic heart disease per 10,000 inhabitants in elderly population according to sex; state of São Paulo, Brazil, 1980 to 2012.

Source: Mortality Information System of the Ministry of Health (SIM/DATASUS).

coefficient $\left(\hat{\beta}_{0}\right)$. The linear reduction $\left(\hat{\beta}_{1}\right)$ was also greater for the older age groups. The mortality coefficients generally demonstrated different magnitudes between sexes in the age groups analyzed, but a similar behavior with regard to the trend throughout the period. Table 2 also displays the results of the analysis of the trend of the coefficients of mortality due to IHD according to sex before and after the beginning of the flu vaccine campaigns. Significant reductions in the mean mortality coefficient $\left(\hat{\beta}_{0}\right)$ were found in both sexes after the beginning of the campaigns, with a slightly more accentuated reduction in the male sex. A reduction in the mean annual increment $\left(\hat{\beta}_{1}\right)$ was also found for the older adults as a whole.

Table 3 displays the annual percent change (APC) and average annual percent change calculated for the entire period (AAPC) of the coefficients of mortality due to IHD according to the joinpoint regression analysis. Based on the APC, the mortality coefficients demonstrated different change points between 1980 and 2012 according to the age groups studied, with significant reductions for men aged 60 to 69 years (1980 to 1996; 1996 to 2012), 70 to 79 years ( 1980 to 2004; 2004 to 2012) and $\geq 80$ years (only 1980 to 2005). For women aged 70 to 79 years, the reduction was significant in two periods (1980 to 2003; 2003 to 2012) and was more accentuated in the latter pe- riod. For women aged $\geq 80$ years, a significant reduction in mortality coefficients was found only for the period from 1980 to 2005, as occurred with the male population. Considering both sexes, the APC of the coefficients of mortality due to IHD demonstrated a significant reduction from 1980 to 2005 (APC $=-2.3 \%$; 95\% CI: $-2.5 \%$ to $-2.1 \%$ ). Regarding the AAPC, a decreasing trend was found for both sexes in all age groups between 1980 and 2012.

Figure 2 displays the standardized coefficients of mortality due to IHD and flu vaccine coverage for all older adults ( $\geq 60$ years) in the period from 2000 to 2012. Mean vaccine coverage was $73.52 \%$ and a weak, inverse, non-significant linear correlation was found in the period $(\mathrm{r}=-0.31 ; \mathrm{p}=$ $0.31)$.

\section{Discussion}

The results of the present study demonstrate a significant reduction in mortality due to ischemic heart disease between 1980 and 2012 among male and female older adults in all age groups, with the reduction more pronounced among individuals aged 80 years or older. The downward trend is similar to that reported for most regions of Brazil in recent decades, especially the southern and southeastern regions ${ }^{2,4,24}$. However, a recent study 
Table 1. Number of deaths and standardized coefficients* of mortality (per 10.000 inhabitants) due to ischemic heart disease in population of older adults according to sex and age; state of São Paulo Brazil, 1980 to 2012.

\begin{tabular}{|c|c|c|c|c|c|}
\hline \multirow[b]{2}{*}{ Year } & \multicolumn{2}{|c|}{ Male } & \multicolumn{2}{|c|}{ Female } & \multirow[b]{2}{*}{ Male/Female Ratio } \\
\hline & $\begin{array}{l}\text { Number of } \\
\text { Deaths }\end{array}$ & $\begin{array}{l}\text { Stand. } \\
\text { Coef. }\end{array}$ & $\begin{array}{l}\text { Number of } \\
\text { Deaths }\end{array}$ & $\begin{array}{l}\text { Stand. } \\
\text { Coef. }\end{array}$ & \\
\hline 1980 & 7199 & 110.84 & 6239 & 91.27 & 1.21 \\
\hline 1981 & 7207 & 106.00 & 6334 & 87.38 & 1.21 \\
\hline 1982 & 7222 & 101.99 & 6269 & 81.39 & 1.25 \\
\hline 1983 & 7675 & 103.24 & 6748 & 83.41 & 1.24 \\
\hline 1984 & 7927 & 102.19 & 6760 & 79.63 & 1.28 \\
\hline 1985 & 7902 & 97.60 & 6899 & 77.56 & 1.26 \\
\hline 1986 & 7743 & 91.81 & 6840 & 73.09 & 1.26 \\
\hline 1987 & 8039 & 91.40 & 7170 & 73.32 & 1.25 \\
\hline 1988 & 8572 & 94.00 & 7366 & 72.28 & 1.30 \\
\hline 1989 & 8431 & 89.43 & 7419 & 69.77 & 1.28 \\
\hline 1990 & 8557 & 87.76 & 7597 & 69.49 & 1.26 \\
\hline 1991 & 8340 & 82.35 & 7519 & 65.07 & 1.27 \\
\hline 1992 & 8440 & 79.98 & 7365 & 60.78 & 1.32 \\
\hline 1993 & 8733 & 83.53 & 7591 & 64.32 & 1.30 \\
\hline 1994 & 8805 & 82.96 & 7772 & 64.79 & 1.28 \\
\hline 1995 & 8640 & 81.69 & 7714 & 63.33 & 1.29 \\
\hline 1996 & 9468 & 79.83 & 8154 & 58.52 & 1.36 \\
\hline 1997 & 9334 & 77.51 & 8384 & 59.26 & 1.31 \\
\hline 1998 & 9065 & 74.57 & 8166 & 56.85 & 1.31 \\
\hline 1999 & 9561 & 77.62 & 8433 & 58.26 & 1.33 \\
\hline 2000 & 9644 & 68.07 & 8611 & 49.21 & 1.38 \\
\hline 2001 & 9470 & 65.93 & 8639 & 48.82 & 1.35 \\
\hline 2002 & 9591 & 66.12 & 8676 & 48.46 & 1.36 \\
\hline 2003 & 10,055 & 68.49 & 8723 & 48.15 & 1.42 \\
\hline 2004 & 10,281 & 69.18 & 8998 & 49.14 & 1.41 \\
\hline 2005 & 9680 & 63.43 & 8381 & 44.61 & 1.42 \\
\hline 2006 & 9996 & 64.79 & 8662 & 45.59 & 1.42 \\
\hline 2007 & 9951 & 52.69 & 8722 & 36.39 & 1.45 \\
\hline 2008 & 10,280 & 53.54 & 8844 & 36.16 & 1.48 \\
\hline 2009 & 10,439 & 52.30 & 8908 & 34.95 & 1.50 \\
\hline 2010 & 10,790 & 52.29 & 9348 & 34.52 & 1.51 \\
\hline 2011 & 11,087 & 53.33 & 9609 & 35.23 & 1.51 \\
\hline 2012 & 11,168 & 53.34 & 9607 & 34.98 & 1.53 \\
\hline Model & \multicolumn{2}{|c|}{$Y=78.18-1.77($ year -1996$)$} & \multicolumn{2}{|c|}{$Y=59.27-1.71($ year -1996$)$} & $Y=1.34+0.009($ year -1996$)$ \\
\hline Trend & \multicolumn{2}{|c|}{$\begin{array}{c}\text { Decreasing } \\
\left(\mathrm{p}<0.001 ; \mathrm{R}^{2}=0.97\right)\end{array}$} & \multicolumn{2}{|c|}{$\begin{array}{c}\text { Decreasing } \\
\left(\mathrm{p}<0.001 ; \mathrm{R}^{2}=0.98\right)\end{array}$} & $\begin{array}{c}\text { Increasing } \\
\left(\mathrm{p}<0.001 ; \mathrm{R}^{2}=0.90\right)\end{array}$ \\
\hline
\end{tabular}

Note: *Standardization using direct method (standard population: the population of the state of São Paulo from the 2010 Census). Source: Mortality Information System of the Ministry of Health (SIM/DATASUS).

on mortality due to cardiovascular disease among adults and older adults in Brazil considering the period between 1980 and 2012 revealed stability in the trend of mortality due to IHD beginning in $2007^{25}$. The reduction in mortality due to cardiovascular disease among older adults may be partially attributed to the expansion in access to healthcare services, such as primary care, health promotion actions, improvements in health care, a reduction in the prevalence of smoking and improvements in socioeconomic aspects ${ }^{3,13}$.

In the present study, the risk of death due to IHD was greater among men and the mean annual coefficient for those aged 80 years or older was 
Table 2. Regression coefficients and statistical significance of trend in coefficients of mortality due to ischemic heart disease according to sex, age group and beginning of flu vaccination campaigns (before and after); state of São Paulo, Brazil, 1980-2012.

\begin{tabular}{lcccc}
\hline \multicolumn{1}{c}{ Sex } & $\hat{\beta}_{0}$ & $\hat{\beta}_{1}$ & p-value & $\mathbf{R}^{2}$ \\
\hline Male & & & & \\
60 to 69 & 46.12 & -0.84 & $<0.001$ & 0.96 \\
70 to 79 & 94.59 & -2.15 & $<0.001$ & 0.96 \\
$\geq 80$ years & 195.78 & -5.46 & $<0.001$ & 0.95 \\
Total & 78.18 & -1.77 & $<0.001$ & 0.97 \\
Before & 91.34 & -1.86 & $<0.001$ & 0.94 \\
After & 62.38 & -1.79 & $<0.001$ & 0.84 \\
Female & & & & \\
60 to 69 & 22.67 & -0.48 & $<0.001$ & 0.95 \\
70 to 79 & 62.48 & -1.85 & $<0.001$ & 0.97 \\
$\geq 80$ years & 175.40 & -5.50 & $<0.001$ & 0.98 \\
Total & 59.27 & -1.71 & $<0.001$ & \\
Before & 71.93 & -1.78 & $<0.001$ & 0.94 \\
After & 44.09 & -1.73 & $<0.001$ & 0.90 \\
Total & & & & \\
60 to 69 & 33.54 & -0.66 & $<0.001$ & 0.96 \\
70 to 79 & 76.49 & -2.01 & $<0.001$ & 0.97 \\
$\geq 80$ years & 183.14 & -5.51 & $<0.001$ & 0.97 \\
Total & 67.71 & -1.76 & $<0.001$ & 0.98 \\
Before* & 80.73 & -1.85 & $<0.001$ & 0.95 \\
After & 52.09 & -1.77 & $<0.001$ & 0.87 \\
\hline Not $\beta^{* *}$ can & & &
\end{tabular}

Note: $\hat{\beta}_{0}$ : mean coefficient of period (per 10,000 inhabitants); $\hat{\beta}_{1}$ : mean annual increment; $p$-value: descriptive level of test; $\mathrm{R}^{2}$ : coefficient of determination. Before (1980 to 1997); After ${ }^{*}$ (1998 to 2012);

Source: Mortality Information System of the Ministry of Health (SIM/DATASUS).

approximately fourfold higher that found in the 60-to-69-year-old age group. Mean coefficients were lower among women, but the increase was approximately sevenfold among those at more advanced ages in comparison to those less than 70 years of age. Therefore, a reduction in the difference between males and females was found regarding the magnitude of the coefficients of mortality due to IHD over time, despite the increasing trend of a higher mortality rate among males in the period. The difference between men and women in mortality due to cardiovascular disease is greater up to the age of 60 years in the state of São Paulo, with a progressive reduction in this difference thereafter ${ }^{26}$.

Laurenti et al. ${ }^{27}$ investigated the morbidity-mortality profile of men in Brazil and found greater mortality in all age groups as well as all groups of causes. Despite the greater morbidity among women, men are more vulnerable to serious chronic conditions that impose limitations and are important causes of death ${ }^{27,28}$. The greater mortality rate among men due to IHD in the present investigation has also been reported in previous studies ${ }^{25,29}$.

The greater mortality rate among men may be explained by the fact that the male population seeks health services less frequently than women, which hinders an early diagnosis of prevalent chronic diseases and impedes the timely adoption of necessary therapeutic and preventive measures ${ }^{26-28}$. According to Mendes ${ }^{29}$, the differences in female and male mortality coefficients among older adults indicate the need for greater attention to the male population in order to improve the quality of the follow up of chronic diseases in earlier phases of life, offer counseling and take preventive measures that can reduce the number of deaths due to ischemic heart and cerebrovascular diseases.

Spike in mortality were found in the trends for both sexes in the present study in 1983/84, 1988, 1990, 1994/1995, 1999, 2004 and 2006. The literature offers epidemiological evidence of an indirect relationship between influenza and mortality due to all causes as well as hospitalizations due to respiratory and cardiovascular problems ${ }^{30,31}$. With the exception of the period between 1999 and $2007^{32}$, records on the subtypes of the influenza virus circulating in Brazil are scarce. However, there are references of an increase in viral circulation in other countries, such as England (1989-90) ${ }^{33}$, the United States ${ }^{34}$, France $^{35}$ and Portugal ${ }^{31}$. Considering the ease and swiftness by which individuals travel about the world, the identification of viral variants with greater virulence in a given country constitutes a risk of circulation in other parts of the planet, which is reflected in higher mortality rates due to all causes as well as due to respiratory conditions and $\mathrm{IHD}^{31}$.

Simonsen et al. ${ }^{36}$ identified excess mortality for all causes in the United States and Nunes et al. ${ }^{31}$ estimated excess deaths due to all causes as well as ischemic heart disease and cerebrovascular diseases in Portugal, both related to the circulation of the A/H3N2 influenza virus. Epidemics with a predominance of this subtype of the virus were recorded in North America during the seasons that preceded its circulation in Brazil ${ }^{34}$. Other authors found a faster rate of seasonal transmission in the years 2004 and 2006/2007, along with excess mortality due to influenza and pneumonia ${ }^{34,37}$. 
Table 3. Estimates annual percentage changes in coefficients of mortality due to ischemic heart disease (IHD) in population of older adults according to sex and age group; state of São Paulo, Brazil, 1980-2012 (Joinpoint regression).

\begin{tabular}{|c|c|c|c|c|c|c|}
\hline Sex & Age Group & Period & APC & $95 \% \mathrm{CI}$ & AAPC & $95 \% \mathrm{CI}$ \\
\hline \multirow[t]{10}{*}{ Male } & 60 to 69 & 1980-1996 & $-1.2^{*}$ & -1.6 to -0.9 & $-1.9^{*}$ & -2.1 to -1.6 \\
\hline & & $1996-2012$ & $-2.5^{*}$ & -2.8 to -2.1 & & \\
\hline & 70 to 79 & $1980-2004$ & $-2.0^{*}$ & -2.3 to -1.8 & $-2.5^{*}$ & -2.8 to -2.1 \\
\hline & & 2004-2012 & $-3.7^{*}$ & -4.8 to -2.6 & & \\
\hline & $\geq 80$ years & $1980-2005$ & $-2.6^{*}$ & -2.8 to -2.3 & $-2.5^{*}$ & -3.6 to -1.3 \\
\hline & & $2005-2008$ & -8.7 & -19.2 to 3.1 & & \\
\hline & & $2008-2012$ & 2.9 & -0.7 to 6.7 & & \\
\hline & Total & $1980-2005$ & $-2.0^{*}$ & -2.2 to -1.8 & $-2.2^{*}$ & -3.2 to -1.2 \\
\hline & & $2005-2008$ & -6.9 & -16.2 to 3.3 & & \\
\hline & & $2008-2012$ & 0.5 & -2.3 to 3.4 & & \\
\hline \multirow[t]{13}{*}{ Female } & 60 to 69 & 1980-1986 & $-3.3^{*}$ & -4.5 to -1.9 & $-2.2^{*}$ & -2.9 to -1.5 \\
\hline & & 1986-1997 & $-0.8^{*}$ & -1.4 to -0.2 & & \\
\hline & & $1997-2005$ & $-3.0^{*}$ & -4.0 to -2.0 & & \\
\hline & & 2005-2009 & $-5.8^{*}$ & -9.6 to -1.8 & & \\
\hline & & 2009-2012 & 1.6 & -2.6 to 5.9 & & \\
\hline & 70 to 79 & $1980-2003$ & $-2.7^{*}$ & -3.0 to -2.5 & $-3.1^{*}$ & -3.5 to -2.8 \\
\hline & & $2003-2012$ & $-4.2^{*}$ & -5.2 to -3.2 & & \\
\hline & $\geq 80$ years & $1980-2005$ & $-2.8^{*}$ & -3.1 to -2.6 & $-3.1^{*}$ & -4.8 to -1.3 \\
\hline & & $2005-2008$ & -9.9 & -25.4 to 8.9 & & \\
\hline & & $2008-2012$ & 0.5 & -4.2 to 5.4 & & \\
\hline & Total & $1980-2005$ & $-2.6^{*}$ & -2.7 to -2.4 & $-2.9^{*}$ & -4.0 to -1.7 \\
\hline & & $2005-2008$ & -8.8 & -19.2 to 3.0 & & \\
\hline & & 2008-2012 & -0.2 & -3.4 to 3.0 & & \\
\hline \multirow[t]{3}{*}{ Total } & & $1980-2005$ & $-2.3^{*}$ & -2.5 to -2.1 & $-2.5^{*}$ & -3.6 to -1.5 \\
\hline & & $2005-2008$ & -7.8 & -17.4 to 2.9 & & \\
\hline & & 2008-2012 & 0.1 & -2.7 to 3.1 & & \\
\hline
\end{tabular}

Note: "Statistically significant ( $<<0.001)$; APC: Annual Percent Change; AAPC: Average Annual Percent Change for entire period (1980 to 2012); CI: confidence interval.

Source: Mortality Information System of the Ministry of Health (SIM/DATASUS).

After the identification of excess mortality due to pneumonia and influenza in the 20032004 season in the United States, 11 outbreaks of flu syndrome were reported in Brazil, distributed among the northern (state of Amazonas), southeastern (states of São Paulo and Minas Gerais) and southern (states of Paraná, Santa Catarina and Rio Grande do Sul) regions of the country, with a high incidence among institutionalized older adults. Data from the Health Surveillance Secretary of the Brazilian Health Ministry indicated a greater proportion of appointments due to the flu syndrome at key healthcare units in these years ${ }^{38}$.

The occurrence of a spike in mortality due to IHD among older adults in 2004 may also be associated with the circulation of the $\mathrm{A} / \mathrm{Fu}$ jian/411/2002 (H3N2) virus. In 2006, the A/ Wisconsin/67/2005 (H3N2) virus, which also circulated in Brazil, was not included in the composition of the vaccine ${ }^{32}$. The increase in the circulation of the $\mathrm{A} / \mathrm{H} 3 \mathrm{~N} 2$ virus in 2010 and 2011 coincided with an increase in the mortality of individuals aged 60 years or older in a study addressing excess mortality due to pneumonia and influenza in the state of São Paulo between 2009 and $2011^{39}$. It should be stressed that the 2009 pandemic affected the population between 20 and 59 years of age with greater intensity, exerting less impact on mortality among older adults due to pneumonia and influenza ${ }^{12,39}$ or other causes.

Coincidence or considerable antigenic proximity of the circulating strains with those that composing the vaccine was generally found since the implementation of the vaccination campaigns in the state of São Paulo and all Brazil ${ }^{15,40}$. However, one must bear in mind that several factors are 


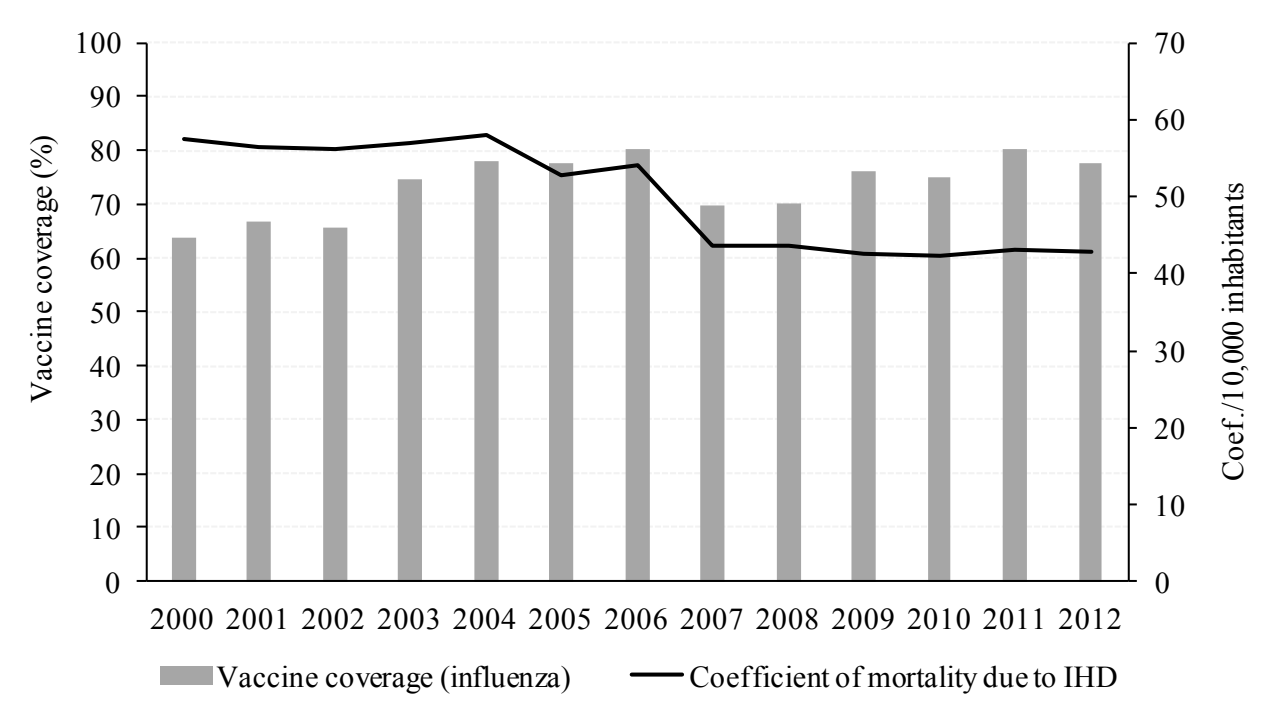

Figure 2. Coefficients of mortality due to ischemic heart disease (age-standardized) and flu vaccine coverage (\%); state of São Paulo, Brazil, 2000 to 2012.

Source: Mortality Information System of the Ministry of Health (SIM/DATASUS).

associated with the specific protection conferred by the vaccine. Moreover, the goal established by the National Immunization Program for vaccination among older adults by 2007 was $70 \%$, which was only reached between 2003 and 2006. In 2008, the goal was increased to $80 \%{ }^{40}$, but this coverage rate was only seen in the year $2011^{19}$.

With regard to the evaluation of trends before and after the availability of the flu vaccine for older adults, a significant reduction was found in the mean post-vaccination coefficients. Evaluating the evolution of mortality and hospital morbidity due to respiratory and cardiovascular disease in the state of Rio Grande do Sul (southern Brazil), Azambuja ${ }^{41}$ found a stabilization of the trend among older adults beginning in 1999, which had previously been increasing, while the decreasing trend of mortality due to myocardial infarction continued, albeit more slowly. In an analysis of mortality due to cardiovascular disease before and after the beginning of flu vaccination campaigns in the city of São Paulo, Mansur et al. ${ }^{17}$ found a significant reduction in mortality due to IHD in the comparison of the pre-vaccine and post-vaccine periods.

Although a reduction in mean coefficients is seen after the implementation of the flu vaccination campaigns, many factors are associated with mortality due to IHD among older adults. One should also bear in mind that the immune response to the vaccination differs according to adverse health conditions and age of individuals ${ }^{42}$. However, despite the official recommendation of vaccination for risk groups ${ }^{15,14}$ and the importance of vaccination to the prevention of cases of hospitalization and death ${ }^{43}$, studies have reported a greater prevalence of vaccination only among older adults with hypertension and those with diabetes ${ }^{44,45}$. The American Heart Association and American College of Cardiology recommend an annual flu vaccine for all patients with atherosclerosis $^{46}$. In Brazil, the Health Ministry and the Brazilian Cardiology Society also recommend an annual vaccine for patients with heart failure ${ }^{16}$.

Using joinpoint regression analysis, it was not possible to identify change points coinciding with or very close to the years in which the vaccination campaigns began. The Brazilian respiratory condition surveillance system indicated an increase in the influenza A (H3N2) virus in 2003 and 2004 as well as an increase in the circulation of respiratory syncytial virus (VSR) in 2002, 2007 and 2010, with VSR identified in 31\% of positive samples in the southeastern region of the country ${ }^{47}$. Particularly in 2003, the circulation of the influenza virus was recorded early - before the national vaccination campaign. Both the early outbreak of influenza A (H3N2) in 2003 and its 
association with severe cases and hospitalizations among older adults ${ }^{34}$ could partially explain the increase in more severe infectious conditions among older adults that year. A greater proportion of medical appointments for influenza syndrome was also recorded at key healthcare units in $2004^{38}$.

For men and women between 70 and 79 years of age, a greater reduction in mortality occurred in 2003/2004. Greater vaccine coverage has also been seen in this age group since the beginning of the campaigns $s^{44,48}$. It is therefore possible that part of the significant reduction in mortality coefficients may be explained by the greater adherence of this subgroup to vaccination. For individuals aged 80 years or older, a significant reduction in mortality coefficients was only found in the period spanning from 1980 to 2005 . The elderly population has been increasing at an accelerated rate and constitutes the group that has grown the most in recent years ${ }^{49}$. Access to better living conditions, information regarding healthy habits, quality health care, vaccination campaigns and other public health actions have exerted an influence on the reduction in mortality rates and, consequently, an increase in life expectancy ${ }^{50}$. Moreover, recent studies conducted in Brazil have contributed to broadening knowledge on aspects related to the living conditions and health of older adults ${ }^{51}$.

No correlation was found between vaccine coverage and coefficients of mortality due to IHD in the entire sample of older adults. One must consider the difference in flu vaccine coverage in this population according to sex, age and city of residence ${ }^{44,48,52}$. Thus, the trend in mortality for the entire set of individuals aged 60 years or older may not reflect the impact of vaccination on specific mortality rates. Data on vaccine coverage that consider these subgroups are needed to enable such analyses.

In the present study, 1998 was considered part of the post-vaccination period, as the first vaccination campaign for the elderly in the state of São Paulo occurred in 1998 in the city of São Paulo. One should also consider that the ecological time series design has limitations related to the use of secondary data, changes in diagnostic criteria over the years and the need for caution in the interpretation of results obtained through correlation analysis.

It is therefore important to consider the complexity of the determination of deaths due to cardiovascular disease, especially ischemic heart disease, among older adults, who often have oth- er chronic conditions as well as varied access to vaccinations. In the present study, one should also consider the impossibility of adjusting the models by other variables related to the outcome (mortality due to IHD).

It should be pointed out that the quality of information and standards for filling out death certificates did not improve in any substantial way, which compromises the quality of mortality information in the period studied ${ }^{53}$ even with the incorporation of the epidemiological death certificates by the Brazilian Health Ministry in $2011^{54}$.

The increase in flu vaccine coverage among individuals with chronic diseases, including cardiovascular disease, is of fundamental importance to public health as a strategy to reduce morbidity and mortality associated with infection by the influenza virus ${ }^{7,14,15}$. However, despite the availability of the vaccine to these groups in Brazil, many individuals with chronic diseases have not yet been vaccinated ${ }^{7,15}$.

As the impact of influenza vaccination on mortality due to cardiovascular diseases is studied little in Brazil, the results of the present investigation underscore the importance of vaccination recommended by health professionals, especially by cardiologists, due to the potential benefit of the influenza vaccine with regard to the prevention of secondary cardiovascular events and, consequently, a possible reduction in mortality due to ischemic heart diseases among older adults.

\section{Conclusion}

The trend of mortality due to ischemic heart disease among older adults demonstrated a reduction in both sexes between 1980 and 2012, especially in the female sex. Moreover, reductions in coefficients of mortality due to IHD were found before and after the implementation of vaccination campaigns for older adults in Brazil. No significant changes in the trend were found in years near the implementation of the flu vaccine program. However, a greater prevalence of vaccination in the population aged 70 to 79 years has occurred in recent years and a significant reduction in mortality coefficients was found in both sexes of this age group beginning in 2003/2004, as demonstrated by the joinpoint regression analysis.

In the present study, the mortality trends due to ischemic heart disease were estimated for the 
population of older adults residing in the state of São Paulo. No linear relationship was found between the mortality coefficients and vaccine coverage in the overall sample of older adults. Although the correlation analysis was exploratory, this study can contribute to broadening the discussion on the topic. Studies on the effectiveness of the flu vaccine in older adults with chronic bases conditions are scarce in Brazil. However, considering the impact of the influenza virus on morbidity and mortality among older adults and individuals with chronic diseases, broadening vaccine coverage among groups that have officially been recommended for vaccinations is a strategy for such individuals to benefit from this specific form of protection.

\section{Collaborations}

AGM Bacurau participated in the conception and design of the study, data collection, analysis and interpretation of the results, drafting of the manuscript and critical review of the content of the article; RO Ferraz participated in the statistical analysis of the data, drafting of the manuscript and critical review of the content of the article; MR Donalisio participated in the drafting of the manuscript and critical review of the intellectual content of the article; PMSB Francisco guided the study, participated in the analysis and interpretation of the data, drafting of the manuscript and critical review of the content.

\section{Acknowledgment}

Acknowledgment to the Brazilian fostering agency CAPES (Coordination Improvement of Higher Education Personnel) for awarding a master's scholarship to AGM Bacurau. 


\section{References}

1. World Health Organization (WHO). Cardiovascular disease. [internet]. 2015 [cited 2016 Jul 19]. Avaiable from: http://www.who.int/cardiovascular_diseases/en/

2. Lotufo PA. Doenças Cardiovasculares no Brasil. In: Serrano Júnior CV, Timerman A, Stefanini E, editores. Tratado de cardiologia SOCESP. Vol.1. 2a ed. Barueri: Manole; 2009. p.7-16.

3. Schmidt MI, Duncan BB, Azevedo e Silva G, Menezes AM, Monteiro CA, Barreto SM, Chor D, Menezes PR. Chronic non-communicable diseases in Brazil: burden and current challenges. Lancet 2011; 377(9781):1946-1961.

4. Piuvezam G, Medeiros WR, Costa AV, Emerenciano FF, Santos RC, Seabra DS. Mortality from Cardiovascular Diseases in the Elderly: Comparative Analysis of Two Five-year Periods. Arq Bras Cardiol 2015; 105(4):371-380.

5. Madjid M, Aboshady I, Awan I, Litovsky S, Casscells SW. Influenza and cardiovascular disease: is there a causal relationship? Tex Heart Inst J 2004; 31(1):4-13.

6. Wong CM, Chan KP, Hedley AJ, Peiris JS. Influenza-associated mortality in Hong Kong. Clin Infect Dis 2004; 39(11):1611-1617.

7. Bricks LF, Carvalhanas TRMP, Domingues CMAS, Pereira SF, Bellei NCJ. Influenza em pacientes com doenças cardíacas crônicas: o que há de novo? J Health Biol Sci 2015; 3(3):165-171.

8. Thompson WW, Moore MR, Weintraub E, Cheng PY, Jing X, Bridges CB, Bresee JS, Shay DK. Estimating influenza-associated deaths in the United States. Am J Public Health 2009; 99(2):225-230.

9. Cohen C, Simonsen L, Kang J, Miller M, McAnerney J, Blumberg L, Schoub B, Madhi SA, Viboud C. Elevated influenza-related excess mortality in South African elderly individuals, 1998-2005. Clin Infect Dis 2010; 51:1362-1369.

10. Madjid M, Miller CC, Zarubaev VV, Marinich IG Kiselev OI, Lobzin YV, Filippov AE, Casscells SW. Influenza epidemics and acute respiratory disease activity are associated with a surge in autopsy- confirmed coronary heart disease death: results from 8 years of autopsies in 34,892 subjects. Eur Heart J 2007; 28(10):1205-1210.

11. Warren-Gash C, Smeeth L, Hayward AC. Influenza as a trigger for acute myocardial infarction or death from cardiovascular disease: a systematic review. Lancet Infect Dis 2009; 9(10):601-610.

12. Brasil. Ministério da Saúde (MS). Secretaria de Vigilância em Saúde. Situação epidemiológica da Influenza Pandêmica (H1N1) 2009 no mundo e no Brasil, até a semana epidemiológica 47 de 2009. Informe Epidemiol. 2009 [acessado 2016 Out 08]; (11): [cerca de 11p]. Disponível em: http://www.prefeitura.sp.gov. br/cidade/secretarias/upload/chamadas/boletim_influenza_se_47_1263819672.pdf

13. Brasil. Ministério da Saúde (MS). Secretaria de Vigilância em Saúde. Departamento de Análise de Situação de Saúde. Plano de ações estratégicas para o enfrentamento das doenças crônicas não transmissiveis (DCNT) no Brasil 2011-2022. Brasília: MS; 2011.

14. World Health Organization (WHO). Influenza (Seasonal). Fact sheet no211. [internet]. [acessado $2016 \mathrm{Jul}$ 19]. Disponível em: http://www.who.int/mediacentre/factsheets/fs211/en/
15. Brasil. Ministério da Saúde (MS). Informe Técnico. Campanha Nacional de Vacinação Contra a Influenza, ano 2016, Brasília, 2016. [acessado 2016 Abr 22]. Disponível em: http://portalarquivos.saude.gov.br/ images/pdf/2016/marco/11/informe-tecnico-campanha-vacinacao-influenza-2016.pdf

16. Sociedade Brasileira de Cardiologia (SBC). III Diretriz brasileira de insuficiência cardíaca crônica. Arq Bras Cardiol 2009; 92(6 Supl. 1):1-71.

17. Mansur AP, Favarato D, Ramires JAF. Vacina contra o vírus da influenza e mortalidade por doenças cardiovasculares na cidade de São Paulo. Arq Bras Cardiol 2009; 93(4):395-399.

18. Façanha MC. Impacto da vacinação de maiores de 60 anos para influenza sobre as internações e óbitos por doenças respiratórias e circulatórias em Fortaleza-CE-Brasil. Jorn Bras Pneumol 2005; 31(5):415-420.

19. Centro de Vigilância Epidemiológica (CVE). Divisão de Imunização e Secretaria de Estado da Saúde de São Paulo. Informe Técnico - Campanha Nacional de Vacinação para o Idoso 2007 "Fique ativo. Vacine-se contra a gripe". BEPA Bol epidemiol paul (online) [internet]. 2007 Jun [acessado 2016 Nov 4]; 4(42): [cerca de 2p.]. Disponível em: http://periodicos.ses.sp.bvs. br/pdf/bepa/v4n42/v4n42a03.pdf

20. Laurenti R, Mello Jorge MHP, Lebrão ML, Gotlieb SLD. Estatísticas de Saúde. São Paulo: EPU; 1987. p.101-46.

21. Latorre MRDO, Cardoso MRA. Análise de séries temporais em epidemiologia: uma introdução sobre os aspectos metodológicos. Rev Bras Epidemiol 2001; 4(3):145-152.

22. Charnet R, Freire CAL, Charnet EMR, Bonvino H Análise de modelos de regressão linear: com aplicações. Campinas: Editora da Unicamp; 2008.

23. Kim HJ, Fay MP, Feuer EJ, Midthune DN. Permutation tests for Joinpoint regression with applications to cancer rates. Stat Med 2000; 19(3):335-351.

24. Mansur AP, Favarato D. Mortality due to Cardiovascular Diseases in Brazil and in the Metropolitan Region of São Paulo: A 2011 Update. Arq Bras Cardiol 2012; 99(2):755-761.

25. Mansur AP, Favarato D. Trends in Mortality Rate from Cardiovascular Disease in Brazil, 1980-2012. Arq Bras Cardiol 2016;107(1):20-25.

26. Sala A, Mendes JDV. Perfil da mortalidade masculina no Estado de São Paulo. BEPA, Bol Epidemiol Paul (online) [periódico na internet]. 2010 Out [acessado 2016 Jul 22]; 2010; 7(82) [cerca de 11p.]. Disponível em: http://periodicos.ses.sp.bvs.br/pdf/bepa/v7n82/ v7n82a03.pdf:15-25.

27. Laurenti R, Jorge MHPM, Gotlieb SLD. Perfil epidemiológico da morbi-mortalidade masculina. Cien Saude Colet 2005; 10(1):35-46.

28. Bastos TF, Canesqui AM, Barros MBA. "Healthy Men" and High Mortality: Contributions from a Population-Based Study for the Gender Paradox Discussion PLoS One 2015; 10(12):e0144520. 
29. Mendes JDV. Perfil da Mortalidade em Adultos por Faixa Etária e Sexo no Estado de São Paulo em 2013. BEPA, Bol Epidemiol Paul (online) [periódico na internet]. 2015 Dez [acessado 2016 Jul 22];12(143): [cerca de 17p.]. Disponível em: http://portal.saude.sp.gov.br/ resources/ses/perfil/profissional-da-saude/destaques// boletim_bepa_144_dez_2015.pdf

30. Warren-Gash C, Bhaskaran K, Hayward A, Leung GM, Lo SV, Wong CM, Ellis J, Pebody R, Smeeth L, Cowling BJ. Circulating influenza virus, climatic factors, and acute myocardial infarction: a time series study in England and Wales and Hong Kong. J Infect Dis 2011; 203(12):1710-1718.

31. Nunes B, Viboud C, Machado A, Ringholz C, Rebelo-de-Andrade H, Nogueira P, Miller M. Excess mortality associated with influenza epidemics in Portugal, 1980 to 2004. PLoS One 2011; 6(6):e20661.

32. Mello WA, Paiva TM, Ishida MA, Benega MA, Santos MC, Viboud C, Miller MA, Alonso WJ. The dilemma of influenza vaccine recommendations when applied to the tropics: the Brazilian case examined under alternative scenarios. PLoS One 2009; 4(4):e5095.

33. Ahmed AE, Nicholson KG, Nguyen-Van-Tam JS. Reduction in mortality associated with influenza vaccine during 1989-90 epidemic. Lancet 1995; 346(8975):591-595.

34. Centers for Disease Control and Prevention (CDC). Estimates of Deaths Associated with Seasonal Influenza - United States, 1976 -2007. MMWR Morb Mort Wkly Rep 2010; 59(33):1057-1062.

35. Carrat F, Flahault A, Boussard E, Farran N, Dangoumau L, Valleron AJ. Surveillance of influenza-like illness in France. The example of the 1995/1996 epidemic. J Epidemiol Commun Health 1998; 52(1 Supl.):32S-8S.

36. Simonsen L, Clarke MJ, Williamson GD, Stroup DF, Arden NH, Schonberger LB. The impact of influenza epidemics on mortality: introducing a severity index. Am J Public Health 1997; 87(12):1944-1950.

37. Simonsen L, Reichert TA, Viboud C, Black-welder WC, Taylor RJ, Miller MA. Impact of influenza vaccination on seasonal mortality in the US elderly population. Arch Intern Med 2005; 165(3):265-272.

38. Brasil. Ministério da Saúde (MS). Secretaria de Vigilância em Saúde. Campanha Nacional de vacinação do idoso - Ano 2005. Slogan: "Ter saúde é o que importa. Vacine-se contra a gripe”. Brasília: MS; 2005. Informe Técnico.

39. Freitas ARR, Francisco PMSB, Donalisio MR. Mortality Associated with Influenza in Tropics, State of São Paulo, Brazil, from 2002 to 2011: The Pre-Pandemic, Pandemic, and Post-Pandemic Periods. Influenza Res Treat 2013; 696274.

40. Brasil. Ministério da Saúde (MS). Secretaria de Vigilância em Saúde. Campanha nacional de vacinação do idoso, 25 de abril a 8 de maio de 2009. Deixe a gripe na saudade. Vacine-se. Brasília: MS; 2009. Informe Técnico.

41. Azambuja MI. Influenza e a Co-Evolução da MorbiMortalidade por Doenças Respiratórias e Cardiovasculares no Rio Grande do Sul. Bol Saúde ESP-RS 2009; 23(1):63-77.

42. Song JY, Cheong HJ, Hwang IS, Choi WS, Jo YM, Park DW, Cho GJ, Hwang TG, Kim WJ. Long-term immunogenicity of influenza vaccine among the elderly: risk factors for poor immune response and persistence. Vaccine 2010; 28(23):3929-3935.
43. Fiore AE, Uyeki TM, Broder K, Finelli L, Euler GL, Singleton JA, Iskander JK, Wortley PM, Shay DK, Bresee JS, Cox NJ. Prevention and control of influenza with vaccines: recommendations of the Advisory Committee on Immunization Practices (ACIP), 2010. MMWR Recomm Rep 2010; 59:1-62.

44. Francisco PMSB, Donalisio MR, Barros MBA, Cesar CLG, Carandina L, Goldbaum M. Vacinação contra influenza em idosos por área de residência: prevalência e fatores associados. Rev Bras Epidemiol 2006; 9(2):162-171.

45. Sato APS, Antunes JLF, Moura RF, Andrade FB, Duarte YAO, Lebrão ML. Factors Associated to Vaccination against Influenza among Elderly in a Large Brazilian Metropolis. PLoS One 2015; 10(4):e0123840.

46. Smith Junior SC, Benjamin EJ, Bonow RO, Braun LT, Creager MA, Franklin BA, Gibbons RJ, Grundy SM, Hiratzka LF, Jones DW, Lloyd-Jones DM, Minissian M, Mosca L, Peterson ED, Sacco RL, Spertus J, Stein JH, Taubert KA. AHA/ACCF Secondary Prevention and Risk Reduction Therapy for Patients With Coronary and Other Atherosclerotic Vascular Disease: 2011 Update: A Guideline From the American Heart Association and American College of Cardiology Foundation. Circulation 2011; 124(3):2458-2473.

47. Freitas FTM. Sentinel surveillance of influenza and other respiratory viruses, Brazil, 2000-2010. Braz J Infect Dis 2013; 17(1):62-68.

48. Moura RF, Andrade FB, Duarte YAO, Lebrão ML, Antunes J LF. Fatores associados à adesão à vacinação anti-influenza em idosos não institucionalizados, São Paulo, Brasil. Cad Saude Publica 2015; 31(10):21572168.

49. Lebrão ML. Epidemiologia do envelhecimento. BIS Bol Inst Saúde (Impr) 2009; (47):23-26.

50. Vasconcelos AMN, Gomes MMF. Transição demográfica: a experiência brasileira. Epidemiol Serv Saude 2012; 21(4):539-548.

51. Neri AL, Yassuda MS, Araújo LF, Eulálio MC, Cabral BE, Siqueira MEC, Santos GA, Moura JGA. Metodologia e perfil sociodemográfico, cognitivo e de fragilidade de idosos comunitários de sete cidades brasileiras: Estudo FIBRA. Cad Saude Publica 2013; 29(4):778-792.

52. Francisco PMSB, Borim FSA, Neri AL. Vaccination against influenza in the elderly: data from FIBRA, Campinas, São Paulo, Brazil. Cien Saude Colet 2015; 20(12):3775-3786.

53. Paes NA. Avaliação da cobertura dos registros de óbitos dos Estados brasileiros em 2000. Rev Saude Publica 2005; 39(6):882-890.

54. Brasil. Ministério da Saúde (MS). Secretaria de Vigilância em Saúde. Departamento de Análise de Situação de Saúde. Manual de Instruções para o preenchimento da Declaração de Óbito. Brasília: MS; 2011.

Artigo apresentado em 21/04/2017

Aprovado em 30/10/2017

Versão final apresentada em 01/11/2017 